\title{
Palavras da diretora
}

Administração pública e gestão social: a produção científica brasileira entre 2000 e 2005 apresenta um quadro geral da produção científica em administração pública e gestão social com base nos dados levantados em 549 artigos publicados nos anais do Enanpad entre 2000 e 2005. Como resultados mais relevantes podem ser observados um aumento da média de autores por artigos, o predomínio do uso do estudo de caso e o aumento da utilização do método quantitativo. Cinco instituições de ensino se destacam como as mais produtivas, concentrando $50 \%$ das publicações no período, e cerca de $56 \%$ dos artigos concentram-se em três estados brasileiros.

O papel do comprador no processo de compras em instituições públicas de ciência e tecnologia em saúde (C\&T/S) tem como objeto de estudo o papel do comprador público nas aquisições de bens e serviços para as instituições públicas de C\&T/S, tendo como referência o CPqAM/Fiocruz. O estudo se reveste de importância, considerando o impacto da atuação do comprador para o bom desempenho das atividades-fim. São questões importantes abordadas no artigo: a função administrativa de compra, o papel do comprador público no processo e a redução de custos na aquisição de materiais para a pesquisa científica.

A resiliência de profissionais angolanos tem como objetivo descobrir que forças ligadas a sentimentos impulsionaram ou facilitaram as ações de angolanos, profissionais de organizações públicas e privadas, para a superação de dificuldades decorrentes dos efeitos devastadores da colonização do país, seguida de uma guerra civil.

Propuesta de una escala para medir la calidad del servicio de los centros de atención secundaria de salud dedica-se ao estudo do conhecimento da qualidade do serviço oferecido pelos centros de saúde no Chile. $\mathrm{O}$ artigo propõe a construção de uma escala confiável e válida, para medir de maneira ótima o serviço prestado à população, composta por cinco subescalas claramente relacionadas e integradas em um único constructo: confiabilidade, empatia, capacidade de resposta, acessibilidade e tangibilidade.

Desafios logísticos às redes de negócios no Brasil: o que podem as parcerias público-privadas (PPPs)?, com foco nos sistemas de transporte, discute a 
distribuição regional dos investimentos prioritários para PPPs, tendo-se por base as condições logísticas para a formação de redes de negócios nas regiões e a perspectiva de estratégia de redução das desigualdades regionais. $\mathrm{O}$ artigo alerta para o fato de que as PPPs podem reforçar essas desigualdades.

Boa leitura!

Deborah Moraes Zouain

Diretora e Editora da RAP 